nghiên cứu tiến hành thiết kế sản phẩm thử nghiệm và ghi nhận được mức độ hài lòng của người sử dụng sau khi sử dụng 30 ngày với mức đánh giá là rất hài lòng. Đây sẽ là cơ sở quan trọng giúp đánh giá sản phẩm về mặt thị trường và góp phần hoàn thiện chế phẩm trước khi thương mại hóa một cách hiệu quả và đáp ứng được kỳ vọng của người sử dụng.

\section{Lờ' CẢM ƠN}

Nghiên cứu này được tài trợ bởi Sở Khoa Học và Công nghệ Thành phố Hồ Chí Minh (DOST HCMC) cho ThS Lê Đặng Tú Nguyên).

TÀI LIỆU THAM KHẢO

1. Lan Ngô T. P., "Các dạng thức sinh kế của cư dân huyện Cần Giờ, Thành phố Hồ Chí Minh: sự tương tác của yếu tố chính sách, thị trường và môi trường", Tapp chí phát triển KH\&CNं, 2016, 10 (3).

2. Earle M. and Earle R., "Creating new foods", The product developer's guide, Chadwick House group Itd, UK. 2009, pp. 1-192.

3. Ford G. T., Smith D. B., Swasy J. L., "An empirical test of the search, experience and credence attributes framework", ACR North American Advances. 1988.

4. Arora R., "Product positioning based on search, experience and credence attributes using conjoint analysis", Joumal of Product \& Brand Management, 2006.

5. Girard T., Dion P., "Validating the search, experience, and credence product classification framework", Journal of Business Research. 2010, $63(9-10), 1079-1087$.

\title{
THỰC TRANG SÀNG LỌC TIỀN SẢN GIÂT, SẢN GIÂTT Ở NHÓM Có YẾU TỐ NGUY Cơ VÀ MộT Số YẾU TỐ LIỂN QUAN TẠI BỆNH VIỆN PHỤ SẢN HẢI PHÒNG
}

\section{TÓM TẮT}

Tiền sản giât là một bệnh lí phức tạp thường xảy ra trong ba tháng cuối của thời kì mang thai và có thể gây ra những tác hại nguy hiểm đến tính mạng của người mẹ và thai nhi. Mục tiêu: Đánh giá thực trạng sàng lọc tiền sản giật, sản giật ở nhóm có yếu tố nguy cơ và một số yếu tố liên quan tại Bệnh viện Phụ Sản Hải Phòng. Đối tượng và phương pháp nghiến cứu: Thai phụ nằm trong nhóm đối tượng nguy cơ bị tiền sản giật có khám, quản lý và kết thúc thai kỳ tại Bệnh viện Phụ Sản Hải Phòng tữ tháng 7/2019 đến tháng 9/2020. Kết quả: từ 07/2019 đến 9/2020 có 476 trường hợp có yếu tố nguy cơ tiền sản giật, sản giật: 306 trường hợp không theo dõi, sàng lọc trong quá trình mang thai chiếm $64,3 \%$ và 170 trường hợp sàng lọc, theo dõi và tuân thủ điều trị chiếm $35,7 \%$. Kết cục thai kì có 3 trường hợp bị tiền sản giật chiếm $1,8 \%$. Ở nhóm tuổi trên 40 có $16,7 \%$ là bị tiền sản giật, nhóm tuổi dưới 40 tỉ lệ tiền sản giật là $1,2 \%$. Có mối liên quan giữa bệnh lý nội khoa với tiền sản giật $p<0,01$. Kết luận: chỉ có $35,7 \%$ thai phụ có yếu tố nguy cơ tiền sản giật tham gia sàng loc, theo dõi, điêu trị. Có mối liên quan giữa bệnh lý nội khoa với tiền sản giật.

Tư khóa: sàng lọc, tiền sản giật, sản giật

\section{SUMMARY}

\section{SITUATION OF PRE-ECLAMPSIA, ECLAMPSIA SCREENING IN RISK GROUP}

*Bênh viên Phu sản Hải Phòng

Chịu trách nhiệm chính: Vũ Văn Tâm

Email: Drvuvantam@gmail.com

Ngày nhận bài: 13.9.2021

Ngày phản biện khoa học: 9.11.2021

Ngày duyệt bài: 15.11.2021

\section{Vũ Văn Tâm*, Lưu Vũ Dũng*}

\section{AND SOME REALATED FACTORS AT HAI PHONG OF OBSSTETRICS AND GYNECOLOGY HOSPITAL}

Pre-eclampsia is a complex condition that might occours during the third trimester of pregnancy and can have life-threatening consequences for the mother and fetus. Purpose: assess the status of preeclampsia, eclampsia screening in risk group and some related factors at $\mathrm{Hai}$ Phong Obstetrics and Gynecology Hospital. Subjects and methods: Pregnant women in the risk group for pre-eclampsia were examined, managned and terminated at the Hai Phong Obstetrics and Gynecology Hospital (7/2019-9/2020). Cross-sectional study. Results: of 474 caces with risk factor of pre-eclampsia, eclampsia, 306 cases were not monitored, screened, followed treatment $(64,3 \%)$ and 170 cases were monitored, screened and followed treatment during pregnancy $(35,7 \%)$. There are 3 cases with pre-eclampsia, accouting for $1,8 \%$. There are $16,7 \%$ patients with age more than 40 years old who were diagnosied pre-eclampsia, the age group less than 40 has pre-eclampsia with $1,2 \%$. There is a relationship between medical condition and preeclampsia with $p<0,01$. Conclusion: there is $35,7 \%$ pregnant women with pre-ecalpmsia risk factor when they are monitored, screened, followed treatment during pregnancy. There is a relationship between medical condition and pre-eclampsia with $\mathrm{p}<0,01$.

Keywords; screening, pre-eclampsia, eclampsia.

\section{I. ĐẠTT VẤN ĐỀ}

Tiền sản giật là một bệnh lí phức tạp thường xảy ra trong ba tháng cuối của thời kì mang thai và có thể gây ra những tác hại nguy hiểm đến tính mạng của người mẹ và thai nhi. Hàng năm 
có khoảng $42 \%$ các trường hợp tử vong me có liên quan đến tiền sản giật và các biến chứng của nó. Tại Hoa Kì, tỉ lệ tiền sản giật đã tăng khoảng $25 \%$ trong vòng hai thập kỉ vừa qua, đặc biệt, nhóm bệnh lí tiền sản giật nặng ngày càng có xu hướng tăng lên $[1,5]$.

Trước những nguy cơ của bệnh lí tiền sản giật, việc sàng lọc và đưa ra những dự báo sớm cũng như điều trị dự phòng ở những trường hợp có nguy cơ cao nhằm góp phần hạn chế những ảnh hưởng của bệnh lí này đến thai kì và sức khỏe sinh sản là hết sức quan trong.

Xuất phát từ thực tế trên, chúng tôi tiến hành nghiên cứu đề tài: "Thực trạng sàng lọc tiền sản giật, sản giật ở nhóm có yểu tố nguy cơ và một số yêu tố liên quan tại Bệnh viện Phụ Sản Hải Phòng".

\section{II. ĐỐI TƯỢNG VÀ PHƯƠNG PHÁP NGHIÊN CỨU}

2.1. Đối tượng nghiên cứu. Thai phụ nằm trong nhóm đối tượng nguy cơ bị tiền sản giật có khám, quản lý và kết thúc thai kỳ tại Bệnh viện Phụ Sản Hải Phòng.

- Thời gian nghiên cứu: từ tháng 07/2019 đến tháng 09/2020.

\section{- Tiêu chuẩn lưa chon:}

+ Tuổi thai từ 12 tuần đến 13 tuần 6 ngày

+ Thai sống

+ Nằm trong nhóm đối tượng nguy cơ cao tiền sản giật sau đây: BMI $>30 \mathrm{~kg} / \mathrm{m}^{2}$; tuổi > 40; Tiền sử mang thai tiền sản giật, sản giật; Tiền sử gia đình bị tiền sản giật, sản giật; Bệnh lí mạn tính (bệnh thận, Basedow, đái tháo đường typ 2, tăng huyết áp mạn tính, lupus ban đỏ hệ thống)

\section{- Tiêu chuẩn loại trứ:}

+ Bệnh nhân đang bị bệnh lý tâm thần

+ Bệnh nhân không đồng ý tham gia nghiên cứu

\subsection{Phương pháp nghiên cứu}

2.2.1.Thiết kế nghiên cứu: nghiên cứu tiến cứu, mô tả cắt ngang.

2.2.2. Chỉ số nghiên cứu:

- Tuổi thai phụ.

- Chỉ số BMI.

- Tiền sử gia đình bị tiền sản giật, sản giật.

- Tiền sử bệnh lý nội khoa mạn tính.

\subsection{Quy trình thực hiện:}

- Bệnh nhân đến khám sàng lọc, khi xác định là thai nghén nguy cơ cao sẽ được Tư vấn xét nghiệm sàng lọc nguy cơ tiền sản giật.
- Bệnh nhân sẽ được hẹn tái khám định kỳ quản lý thai nghén đến lúc sinh. Trong quá trình quản lý thai nghén xác định sản phụ có bị tiền sản giật không, thời điểm xuất hiện tiền sản giật.

- Ghi nhận các thông tin vào bảng thu thập số liệu sẵn có.

- Xử lý và phân tích số liệu.

2.4. Xử lý số liệu: Dựa trên phần mềm SPSS22.0.

2.5. Đạo đức nghiên cứu: Các thông tin cá nhân đều được đảm bảo giữ bí mật. Nghiên cứu nhằm mục đích đóng góp vào việc bảo vệ và nâng cao sức khỏe. Đề tài đã thông qua hội đồng khoa học Bệnh viện Phụ Sản Hải Phòng.

\section{KẾT QUẢ NGHIÊN CỨU}

3.1. Thực trang khám sàng loc TSG, SG ở nhóm có yếu tố nguy cớ . Trong khoảng thời gian từ 07/2019 đến 09/2020 chúng tôi ghi nhận 476 thai phụ có 1 trong các yếu tố nguy cơ tiển sản giật, sản giật đều được tư vấn theo dõi, sàng lọc và chẩn đoán bệnh.

Bảng 3.1. Thức trạng khám sàng lọc TSG, SG ở nhóm thai phụ có yếu tốnguy cớ

\begin{tabular}{|c|c|c|}
\hline & $\mathbf{n}$ & $\mathbf{\%}$ \\
\hline Không & 306 & 64,3 \\
\hline Có & 170 & 35,7 \\
\hline Tuối cao (40 tuối) & 6 & 3,5 \\
\hline Béo phì & 11 & 6,5 \\
\hline Tiền sữ tiền sản giật & 11 & 6,5 \\
\hline Bệnh nội khoa mạn tính & 30 & 17,6 \\
\hline Dộng mạch tử cung bệnh lý & 78 & 45,8 \\
\hline
\end{tabular}

Nhận xét: Trong thời gian nghiên cứu chúng tôi ghi nhận có 170 trường hợp có làm xét nghiệm sàng lọc tiền sản giật chiếm 35,7\% tổng số trường hợp.

Trong nhóm này chúng tôi nhận thây tỉ lệ me có tử cung bệnh lí cao nhất với 78 trường hợp chiếm $45,8 \%$, thấp nhất là tiền sử có tiền sản giật và me béo phì chiếm $6,5 \%$.

3.2. Một số yếu tố liên quan đến tiên sản giật ở thai phụ nguy cơ cao tại Bệnh viện Phụ Sản Hải Phòng. Trong tổng số 170 trường hợp tham gia sàng lọc tiền sản giật, sản giật có theo dõi đến khi kết thúc thai kì. Kết quả cho thấy: kết cục thai kì ở nhóm nghiên cứu có 3 trường hợp bị tiền sản giật chiếm 1,8\% trong khi đó 167 trường hợp chiếm 98,2\% là không bị tiền sản giật.

Bảng 3.2. Môi liên quan giữa tuổi thai phụ và tiền sản giật

\begin{tabular}{|c|c|c|c|c|}
\hline \begin{tabular}{|ll} 
Tuổi me & Tiền sản giật \\
\end{tabular} & Có n (\%) & Không n (\%) & Tổng & $\mathbf{p}$ \\
\hline \begin{tabular}{|l}
$>40$ tuối \\
$<40$ tuối
\end{tabular} & $\frac{1(16,7)}{2(12)}$ & $\frac{5(83,3)}{162(98,8)}$ & $\frac{6(100)}{164(100)}$ & $>0,2$ \\
\hline
\end{tabular}


OR (KTC - 95\%)

$16(1,25: 209)$

Nhận xét: ở nhóm tuối trên 40 chúng tôi ghi nhận có 1 trường hợp chiếm $16,7 \%$ là bị tiền sản giật, trong khi ở nhóm tuổi dưới 40 có 2 trường hợp chiếm 1,2\%.

Bảng 3.3. Cân nặng thai phụ liên quan tiền sản giật

\begin{tabular}{|c|c|c|c|c|}
\hline \begin{tabular}{|ll} 
BMI & Tiền sản giật \\
\end{tabular} & Có n (\%) & Không n (\%) & Tổng & $\mathbf{p}$ \\
\hline$\geq 30$ & $0(0)$ & $11(100)$ & $11(100)$ & \multirow{2}{*}{$p=0,6$} \\
\hline$<30$ & $3(1,9)$ & $156(98,1)$ & $159(100)$ & \\
\hline
\end{tabular}

Nhận xét: ở nhóm BMI $\geq 30$ chúng tôi nhận thấy không có xuất hiện bệnh lí của tiền sản giật, ở nhóm < 30 chúng tôi ghi nhận có 3 trường hợp chiếm 1,9\% có xuất hiện tiền sản giật, tuy nhiên sự khác biệt này không có ý nghĩ̃a thống kê

Bảng 3.4. Doppler động mạch tử cung và bệnh lý tiền sản giật

\begin{tabular}{|c|c|c|c|c|}
\hline Động mạch tử cung & Có n (\%) & Không n (\%) & Tổng & $\mathbf{p}$ \\
\hline Bình thường & $0(0)$ & $92(100)$ & $92(100)$ & \multirow{2}{*}{$p>0,05$} \\
\hline Bệnh lý & $3(3,9)$ & $75(96,1)$ & $78(100)$ & \\
\hline
\end{tabular}

Nhận xét: ở nhóm động mạch tử cung bình thường $100 \%$ các trường hợp không xuất hiện bệnh lí tiền sản giật, ở nhóm động mạch tử cung bệnh lí chúng tôi ghi nhận có 3 trường hợp chiếm 3,9\% có xuất hiện tiền sản giật, tuy nhiên sự khác biệt này không có ý nghĩ̉a thống kê.

Bảng 3.5. Bệnh lý nội khoa và tiền sản giật

\begin{tabular}{|c|c|c|c|c|}
\hline Bệnh lí nội khoa & Có n (\%) & Không n (\%) & Tổng & p \\
\hline Bệnh lí & $2(6,6)$ & $28(93,4)$ & $30(100)$ & \multirow{2}{*}{$p<0,01$} \\
\hline Bình thường & $1(0,07)$ & $139(99,93)$ & $140(100)$ & \\
\hline
\end{tabular}

Nhận xét: ở nhóm không có bệnh lí nội ngoại khoa có 1 trường hợp chiếm 0,07\% có xuất hiện tiền sản giật.

\section{BÀN LUÂ̂N}

4.1. Thực trạng khám sàng lọc TSG, SG ở nhóm có yếu tố nguy cớ. Theo bảng 3.1 chúng tôi nhận thấy trong khoảng thời gian từ 07/2019 đến 9/2020 có 306 trường hợp không đồng ý tham gia vào nghiên cứu chiếm $64,3 \%$ và ghi nhận 170 trường hợp đồng ý tham gia vào nghiên cứu.

Với thiết kễ nghiên cứu là mô tả cắt ngang tiến cứu, trong khoảng thời gian nghiên cứu chúng tôi nhận thấy số lượng thai phụ có nguy cơ tham gia vào nghiên cứu vẫn còn là một con số khiêm tốn, chỉ chiếm $35,7 \%$ các trường hợp có nguy cơ. Hiện nay tuy có sự phát triển của mạng internet cũng như mạng xã hội phần lớn các thai phụ vẫn chưa có sự hiểu biểt một cách rõ rệt về bệnh này nên sư tham gia của bệnh nhân trong việc sàng lọc vấn còn chiếm môt tỉ lệ thấp, hơn nữa hiện nay với sự phát triển của mạng lưới y tế tư nhân nên có một số lượng lớn bệnh nhân khám ở các phòng khám tư và ở bệnh viện tư. Vì những lí do đó chúng tôi thây trong khoảng thời gian nghiên cứu tổng số bệnh nhân của chúng tôi là 476 trường hợp và cũ̉ng chỉ có 170 trường hợp đồng ý tham gia và nghiên cứu.

4.2. Một số yếu tố liên quan đến tiền sản giật ở thai phụ nguy cơ cao tại Bệnh viện

\section{Phụ Sản Hải Phòng}

- Liên quan tuổi, BMI và nguy cơ tiền sản giật. Theo Bảng 3.2 chúng tôi nhận thấy nhóm tuổi me trên 40 tuổi có nguy cơ xuất hiện tiền sản giật gấp 16 lần so với nhóm dưới 40 tuổi. Còn theo Bảng 3.3 chúng tôi ghi nhận ở nhóm $\mathrm{BMI}<30$ có 3 trường hợp chiếm tỉ lệ $1,9 \%$ là có xuất hiện tiền sản giật.

Còn theo một số các tác giả khác như Kevin Spencer (2007) [2], Leona Y. Poon (2010) [3], Parra Cordero (2013) [4] đều đã đưa ra các kết quả nghiên cứu của mình cho thây nhóm xuất hiện bệnh lí tiền sản giật có BMI cao hơn so với nhóm thai phụ không xuất hiện bệnh lí tiền sản giật. BMI là một trong những yếu tố nguy cơ tiền sản giật. Thậm chí có tác giả còn so sánh với trường hợp BMI mức $21 \mathrm{~kg} / \mathrm{m}^{2}$ làm xuất hiê̂n nguy cơ tiền sản giật tăng gấp 2 nếu BMI 26 $\mathrm{kg} / \mathrm{m}^{2}$ (OR 2,1; 95\% CI: 1,4 - 3,4), tăng gần gấp 3 nếu BMI $30 \mathrm{~kg} / \mathrm{m}^{2}$ (OR2,9; 95\% CI: 1,6 - 5,3) [5]. Tương tự, Sohlberg và cộng sự (2012) [6] đã chứng minh béo phì độ II, III tăng nguy cơ tiền sản giật gấp 4 lần (OR 4,0; 95\% CI: 3,7 4,4). Phân tích của Emily Bartsch (2016) [7] cho thây tăng nguy cơ tiền sản giật nếu $\mathrm{BMI}>30$ $\mathrm{kg} / \mathrm{m}^{2}$ (RR 2,8; 95\% CI: 2,6 - 3,1). Thậm chí các tác giả cũng đưa ra các mô hình về yểu tố nguy 
cơ và tiên lượng việc xuất hiện tiền sản giật sớm và tiền sản giật muộn.

Trong nghiên cứu của chúng tôi tuy ghi nhận có 11 trường hợp BMI trên $30 \mathrm{~kg} / \mathrm{m}^{2}$ nhưng tất cả những trường hợp này đều không xuất hiện bệnh lí tiên sản giật trong thời gian mang thai và theo dõi tại Bệnh viện Phụ Sản Hải Phòng, còn trong nhóm BMI dưới $30 \mathrm{~kg} / \mathrm{m}^{2}$ chúng tôi ghi nhận có 3 trường hợp có xuất hiện tiền sản giật. Chúng tôi cũng nhận thấy cả 3 trường hợp này đều có những yếu tố nguy cơ khác và đều là các yếu tố nguy cơ cao của tiền sản giật đã được chứng minh cụ thể bằng nhiều nghiên cứu khác. Chúng tôi lựa chọn ngưỡng cắt $30 \mathrm{~kg} / \mathrm{m}^{2}$ vì đó là tiêu chuẩn béo phì của WHO [8].

Như vậy từ rất nhiều các mô hình nghiên cứu khác và với kết quả nghiên cứu của mình chúng tôi càng có cơ sở để khẳng định rằng tuổi mẹ cũng như BMI có mối liên quan chặt chẽ và làm tăng nguy cơ của tiền sản giật ở những thai phụ có thể chưa có tiền sử bệnh lí bất thường trong thời kì mang thai.

Liên quan Doppler động mạch tử cung với nguy cơ tiền sản giật và hiệu quả sàng lọc tiền sản giật dựa vào Doppler động mạch tử cung

Theo kết quả của bảng 3.4 chúng tôi nhận thây ở nhóm siêu âm có tử cung bệnh lí có 3 trường hợp xuất hiện tiền sản giật chiếm 3,9\%, cũng trong nghiên cứu này ở nhóm các trường hợp có động mạch tử cung bình thường chúng tôi không ghi nhận có xuất hiện tiền sản giật.

Một tổng quan hệ thống trên 18 nghiên cứu với 55.974 trường hợp của tác giả Velauthar và cộng sự đã cho thấy giá trị siêu âm doppler động mạch tử cung (PI và RI) tại thời điểm $11-14$ tuần thai kỳ có thể dự báo $47,8 \%$ tiền sản giật sớm và $26,4 \%$ tiền sản giật mọi thời điểm [9]. Tương tự, một nghiên cứu khác cho thấy khi phối hợp với các yếu tố nguy cơ me, UtA - PI ở thời điểm $11-13$ tuần 6 ngày thai kỳ có thể dự báo $45 \%$ tiền sản giật sớm với tỷ lệ dương tính giả $10 \%$. Có nhiều nghiên cứu trong nước đánh giá vai trò dự báo TSG dựa vào UtA-PI một số nghiên cứu sử dụng giá trị UtA - PI trung bình, một số nghiên cứu vai trò dự báo tiền sản giật bằng đơn độc UtA - PI, một số nghiên cứu có hiệu chỉnh và̀ đánh giá thông qua giá trị MoM.

Liên quan giữa bệnh lý nội khoa và tiền sản giật. Theo bảng 3.5 chúng tôi ghi nhận trong nhóm có bệnh lí nội khoa có 2 trường hợp chiếm $6,6 \%$ số trường hợp có xuất hiện tiền sản giật, còn ở nhóm bình thường chỉ có $0,07 \%$ trường hợp có xuất hiện tiền sản giật, sự khác biệt này là có ý nghĩa thống kê với $p<0,01$.
Một trong những yếu tố nguy cơ được nhắc đến nhiều nhất có liên quan đến các bệnh lí tiền sản giật sớm hay muộn trong thai kì là tăng huyết áp, các bệnh lí về thận, tim mạch, đái tháo đường. Điêu này đã được một loạt các nghiên cứu chứng minh trong một khoảng thời gian dài và càng được củng cố hơon nữa. Theo khuyến cáo của NICE và ACOG yếu tố nguy cơ cao của lần mang thai này có thể xuất hiện tiền sản giật là tiền sử mang thai bị tiền sản giật, các bệnh lí nội khoa mạn tính, đái tháo đường thai kì, tăng huyết áp mạn tính và bệnh thận mạn tính [1].

Nhiều nghiên cứu trước đây cũng đã chỉ ra rằng các bệnh lí nội khoa có mối liên quan chặt chẽ với tiền sản giật và thậm chí điều này đã được đưa vào trong sách giáo khoa giảng day tại các trường đại học. Điều này một lần nửa lại được chứng minh ở nghiên cứu của chúng tôi khi có mối liên quan chặt chẽ giữa tiền sản giật với nhóm các bệnh lí nội khoa. Tuy nghiên cứu của chúng tôi có cõ̃ mẫu không lớn nhưng cũng đã góp phần khẳng định thêm một cách chặt chẽ mối liên quan giữa bệnh lí nội khoa với tiền sản giật. Ngay trong nghiên cứu này chúng tôi cũng đã tiến hành tư vấn và sàng lọc chặt chẽ cho nhóm đối tượng này để tránh phát hiện chậm làm tăng nặng tình trạng bệnh lí của bệnh nhân hoặc bỏ sót bệnh nhẩn góp phần làm giảm tỉ lệ bệnh suất và tử suất của nhóm đối tượng này trong quần thể chung của năm 2019 và 2020.

\section{KẾT LUÂN}

- Số lượing thai phụ có nguy cơ tiền sản giật, sản giật sàng lọc, theo dõi trong thời gian mang thai chiếm chiếm $35,7 \%$. Trong đó, nguy cơ me có tử cung bệnh lí cao nhất là $45,8 \%$, thấp nhất là tiền sử có tiền sản giật và mẹ béo phì cùng chiếm $6,5 \%$.

- Có mối liên quan giữa bệnh lí nội khoa với tiền sản giật.

\section{KHUYẾN NGHI}

Cần triển khai tư vấn thường quy cho các thai phụ đi khám thai định kì lúc 12 tuần. Sàng lọc bệnh lí nền và khuyến cáo nên làm sàng lọc sớm tiển sản giật ở nhóm thai phụ có nguy cơ cao để dự báo, phát hiện và dự phòng các kết cục cho me và thai.

\section{TÀI LIỆU THAM KHẢO}

1. Obstetricians A. C., Gynecologists (2019), "Gestational hypertension and preeclampsia. ACOG Practice bulletin no. 202", Obstet Gynecol, 133, pp. 211-218.

2. Spencer K., Cowans N., Chefetz I., et al. (2007), "First-trimester maternal serum PP-13, 
PAPP-A and second-trimester uterine artery Doppler pulsatility index as markers of pre-eclampsia", Ultrasound in Obstetrics and Gynecology: The Official Journal of the International Society of Ultrasound in Obstetrics and Gynecology, 29 (2), pp. 128-134.

3. Poon L., Kametas N., Chelemen T., et al. (2010), "Maternal risk factors for hypertensive disorders in pregnancy: a multivariate approach", Journal of human hypertension, 24 (2), pp. 104-110.

4. Parra-Cordero M., Rodrigo R., Barja P., et al. (2013), "Prediction of early and late pre-eclampsia from maternal characteristics, uterine artery Doppler and markers of vasculogenesis during first trimester of pregnancy", Ultrasound in Obstetrics \& Gynecology, 41 (5), pp. 538-544.

5. Bodnar L. M., Ness R. B., Markovic N., et al. (2005), "The risk of preeclampsia rises with increasing prepregnancy body mass index", Annals of epidemiology, 15 (7), pp. 475-482.

6. Sohlberg S., Stephansson 0. ., Cnattingius S., et al. (2012), "Maternal body mass index, height, and risks of preeclampsia", American journal of hypertension, 25 (1), pp. 120-125.

7. Bartsch E., Medcalf K. E., Park A. L., et al. (2016), "Clinical risk factors for pre-eclampsia determined in early pregnancy: systematic review and meta- analysis of large cohort studies", Bmj, 353

8. Organization W. H. (1995), "Physical status: The use of and interpretation of anthropometry, Report of a WHO Expert Committee".

9. Velauthar L., Plana M., Kalidindi M., et al. (2014), "First-trimester uterine artery Doppler and adverse pregnancy outcome: a meta-analysis involving 55974 women", Ultrasound in Obstetrics \& Gynecology, 43 (5), pp. 500-507.

\section{KHẢO SÁT CHẤT LƯợNG CUộC SỐNG CỦA NGƯờI BỆNH UNG THƯ PHỔI KHÔNG TẾ BÀO NHỎ TRƯỚC VÀ SAU XẠ TRI TẠI KHOA XẠ LỒNG NGỰC, BỆNH VIỆN K}

\begin{abstract}
TÓM TẮT.
Mục tiêu :Khảo sát chất lương cuộc sống của người bệnh ung thư phổi không tế bào nhỏ (UTPKTBN) trước và sau xạ trị tại khoa Xa Lồng ngực, Bệnh viện K. Đối tượng, phướng pháp :105 người bểnh được chẩn đoán là Unng thư nguyên phát tai phổi giai đoạn III điều trị tia xa. Sử dụng thang điểm Bộ câu hỏi EORTC QLQ-C30 để khảo sát chất lượng cuộc sống của người bệnh tại 2 thời điểm trước và sau xạ trị. Kết quả: Trước xạ trị điểm trung bình CLCS cao nhất thuộc về lĩnh vực "Chức năng cảm xúc" với 72,8 điểm, xếp thứ hai là "Chức năng nhận thức" đạt 72,0 điểm, còn thấp nhất là lĩnh vực "Chức năng hoạt động" 31,7 điểm. Sau xa trị điểm trung bình về lĩnh vực chức năng lần lượt là: nhận thức $(77,2)$, cảm xúc $(76,7)$, xã hội $(71,8)$, thể chất $(67,1)$, hoạt động $(31,2)$. Chất lượng cuộc sống chung ở mức trung bình cả 2 thời điểm nghiên cứu là 54,0 điểm. Lĩnh vực triệu chứng của người bệnh UTPKTBN giai đoạn III kể cả trước và sau xạ trị có điểm trung bình lần lượt là: mệt mỏi $(68,2 ; 65,8)$, đau $(54,4 ; 43,6)$, chán ằn $(53,0$; $50,2)$, mất ngủ $(52,5 ; 28,5)$ và khó thở $(31,7 ; 25,9)$. Các triêu chứng buốn nôn, táo bón và tiêu chảy ít gặp với điểm trung bình dưới 20 điểm cả 2 thời điểm. Vấn đề khó khăn tài chính của đối tượng nghiên cứu có điểm ở mức trung bình $(60,4 ; 63,8)$. Kết luận: Với nhóm đối tượng nghiên cứu thì vấn đề chức nẳng của người bệnh tốt, vấn đề về sức khỏe ở mức độ trung bình.
\end{abstract}

*Bệnh viện $K$

Chịu trách nhiệm chính: Vũ Thị Thu Nga

Email: indijon09@gmail.com

Ngày nhận bài: 14.9.2021

Ngày phản biện khoa học: 10.11.2021

Ngày duyệt bài: 16.11.2021
Vũ Thị Thu Nga*

Tư khóa: Ung thư phổi không tế bào nhỏ; Chất lượng cuộc sống; Xạ trị

\section{SUMMARY \\ SURVEY ON THE QUALITY OF LIFE OF NON-SMALL CELL LUNG CANCER PATIENTS BEFORE AND AFTER RADIATION AT THE THORACIC RADIOLOGY DEPARTMENT, K HOSPITAL}

Objectivity: To survey the quality of life of patients with non-small cell lung cancer (NSCLC) before and after radiation therapy at the Department of Thoracic Radiation, K Hospital. Subjects and methods: 105 patients were diagnosed as: Primary cancer in the lung stage III treated with radiation. Using the EORTC QLQ-C30 questionnaire scale to survey the quality of life of patients at 2 time points before and after radiation therapy. Results: Before radiation therapy, the highest average score of $\mathrm{QOL}$ belonged to the field of "Emotional function" with 72.8 points, second was "Cognitive function" with 72.0 points, and the lowest was in the field of "Emotional function" with 72.8 points. "Active function" 31.7 points. After radiotherapy, the average scores in functional areas are: cognitive (77.2), emotional (76.7), social (71.8), physical (67.1), activity ( 31.2). Overall quality of life at the average of both study points was 54.0 points. The common symptom areas of patients with stage III NSCLC, both before and after radiotherapy, are fatigue $(68.2 ; 65.8)$, pain (54.4; 43.6), anorexia (53.0). ; 50.2), insomnia (52.5; $28.5)$ and shortness of breath (31.7; 25.9). Symptoms of nausea, constipation and diarrhea were uncommon with an average score of less than 20 points in both time points. The problem of financial difficulty of the 